\title{
SAFETY ASSESSMENT FOR SPATIAL DEVELOPMENT
}

\author{
DAVID ŘEHÁK, KATEŘINA SIKOROVÁ, PAVEL SENOVSKÝ
}

VSB - Technical University of Ostrava, Faculty of Safety Engineering, Lumírova 13, 70030 Ostrava-Výškovice, Czech Republic; e-mail: david.rehak@vsb.cz, katerina.sikorova@vsb.cz,pavel.senovsky@vsb.cz

\begin{abstract}
Rehák D., Sikorová K., Senovský P.: Safety assessment for spatial development. Ekológia (Bratislava), Vol. 32, No. 2, p. 220-241, 2013.

The article deals with the problems of operable safety assessment for spatial development to promote the preventive protection of population, engineering infrastructure and the environment against negative effects of spatial development. At present, many methods available for semi-quantitative risk analysis exist, but there is no method completely suitable for assessment of risks associated with spatial development. This is why a new method - Spatial Development Impact Assessment, which is based philosophically on the Fire \& Explosion Index, Hazard \& Vulnerability Index and Hazard \& Impact Index - is presented in the article. The article describes the main tools of this method, namely assessment process algorithm, catalogue of hazard and asset groups and spatial development impact matrix. It demonstrates, by a case study on the safety assessment for spatial development using an online software tool developed for this purpose, the application of the method.
\end{abstract}

Key words: environmental protection, population, technical infrastructure, analytic method, risk.

\section{Introduction}

Spatial development is a significant part of development for human population. Through the spatial development, people tried to adapt to newly populated areas according to their needs and increase utility value in their benefit. This was particularly the construction of settlements and other components of equipment in this area. With agglomeration sprawl occurs also an approximation of the dense settlement into the direct proximity of heavily industrially used areas, which carries with it additional risks with the potential to affect not only the environment but also the health of the population directly.

The basic strategic document in the area of safety for spatial development in the Czech Republic is the State Environmental Policy of the Czech Republic (Ministry of Environment, 2004a), which defines a consensual framework for long-term and mid-term development of environmental aspect of sustainable development (Belčáková, 2012). The second strategic document is the Strategy of Sustainable Development of the Czech Republic (Ministry of Environment, 2004b). This strategy creates a framework for elaborating the materials of conceptual character (departmental policies and action programmes). It is a starting point for strategic decision making within individual departments, inter-departmental co-operation and the co-operation among interest groups. 
The spatial development in the Czech Republic follows the Act on Spatial Planning and Building Code (Act, 2006). The spatial development is carried out in compliance with this Act and on the basis of spatial planning. The task of spatial planning is, besides other things, to assess the effects of the policy of spatial development, the principles of spatial development and a spatial plan on a balanced relation between spatial conditions and the environment, economic development and a unity of the population living on the territory (hereinafter 'assessment of impacts on the sustainable development of the territory').

When assessing the consequences of concepts and intentions, the procedure is followed according to the Act on Environmental Impact Assessment (Act, 2001), which, in compliance with the law of the European Union (Council Directive, 1985, 1997; Directive, 2001), amends the assessment of impacts on the environment and public health as well as on the procedures followed by physical entities, legal entities, administrative authorities and territorial self-administration units (municipalities and districts) in the course of assessment. This Act is followed when assessing the impacts on public health and the environment. However, assessment of the impacts of spatial development on population and technical infrastructure cannot be performed according to the Act in order to ensure a social and technical safety for spatial development.

To this purpose it is appropriate to find solutions in a proactive approach to environmental protection by using preventive tools. However, at present there is no methodology that would be able to evaluate the safety of spatial development (Navratilova et al. 2013). On this basis, are presented below, at least such methodologies, which deal with similar problems, which can serve as a basis for further development process.

The article follows and further elaborates, with an emphasis on practical application, a contribution presented at the end of 2010 in a national journal (Řehák, Dvorak, 2010) and a case study

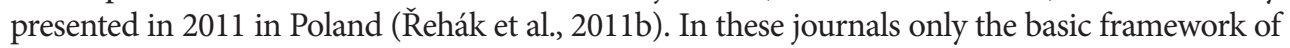
this problem was presented.

\section{Material and methods}

This part of article presents the most significant materials, methods and approaches that have become the bases for the formation of algorithm for the process of safety assessment for spatial development.

\section{Semi-quantitative methods of risk analysis}

At present there are many methods of risk analysis employed in the area of safety engineering (Bartlova, Balog, 2007; Senovsky et al., 2009; Danihelka et al., 2006), but none of them is fully suitable for the analysis and assessment of safety of spatial development. Detailed analysis of the subject matter identified three relevant semi-quantitative methods of risk analysis on which the development of a new tool of safety assessment for spatial development is based. These methods are Fire \& Explosion Index, Hazard \& Vulnerability Index and Hazard \& Impact Index.

The Fire \& Explosion Index Method (AIChE, 2010) is a step-by-step index system the aim of which is to realistically assess the threat of fire and explosion depending on the potential of technological facility. The quantitative parameters used in the system are based on the historical data acquired from the detailed analysis of accidents in the past as well as on the preventive measures commonly used in technological practice. The aim of the Fire \& Explosion Index may be seen mainly in the quantification of possible damage caused by fire or explosion, the identification of equipment which may escalate the accident and inform the management on the outcomes of the analysis.

By a thorough analysis of methods and systems of impact assessment, it seems that the step-by-step analysis of the Fire \& Explosion Index Method is an optimal decision-making algorithm. Its advantages are mainly simplicity, clarity and unambiguity when implementing individual stages of the method. However, the process of the method itself is totally 
unsuitable as it is specifically aimed only at areas of hazard, i.e. fire and explosion. At the same time, it may be stated that the method is rather time demanding.

Another necessary condition of objective evaluation is a complex assessment of all risks in the territory. This approach began to promote from the beginning of the 21st century. In this context, we can mention the Swiss KATARISK (2003) or even HVA method, sometimes also known as HVE method: H - hazard, V - vulnerability, E - value of the elements at risk (SIPROCI, 2007). For assessment of the territory, this method was promoted by the project SIPROCI (International Response to Natural and Man-made catastrophes SIPROCI), which from 2004 to 2007 has had the task of participating countries to predict, prevent and respond to natural or man-made disasters. One of the outputs of the project was to create a uniform methodology for mapping risks.

The Hazard \& Vulnerability Index Method (Vojkovska, Danihelka, 2002) is applied for assessing the impact the accidents have on the environment. It may also be used for assessing and prioritizing the risks on the territories up to the size of the region. The assessment of larger territorial units would require the implementation of geographic information system (GIS). The method is based on clear mathematical procedures which provide clear overview of final index values and subsequent determination of impacts the hazardous substances have on the environment (Sikorova, 2009). At the same time, the clarity of indexation is supported by the principle of separate indexation for individual environmental elements. Therefore, the above-mentioned principle was applied not only within the indexation, but also in the classification of negative aspects of spatial development and areas of their impacts.

The method of preventive military training environmental impact assessment called the Hazard \& Impact Index (Řehák et al., 2011a) is a semi-quantitative method which was developed by the team of Czech environmentalists from 2007 to 2009 within the project of the Czech Academy of Sciences Grant Agency. After being completed in the first half of 2010, it was the subject of practical testing. After successful negotiations with the Czech Ministry of Defence Logistic Section, the method was implemented in the Army of the Czech Republic in the form of guidelines in June 2010 (Rehak et al. 2010). The algorithm used the outcomes of study aimed at the methods of technological risks analysis based on a semi-quantitative assessment. The final algorithm comprises individual steps determining the level of risk to the environment caused by military training.

Its advantages are mainly simplicity, clarity, unambiguity and operability when applying the individual stages of the method. Therefore, the assessment algorithm was used when developing the assessment process algorithm, which is the key part of the environmental tool for spatial development impact assessment.

\section{Geographic information system tools}

GIS is one of the suitable tools which can be used for risk analysis of territorial unit in general, e.g. for the risk source localization, creation of emergency scenarios or combined risk assessment in the territory (Hrdina et al., 2010). GIS software, convenient as a support for graphical and geospatial evaluation of safety for spatial development is, for example, ESRI product ArcGIS for Desktop - Advanced (previously known as ArcInfo). This software contains more than 200 tools for advanced analysis and geoprocessing, data management, mapping and visualization, advanced editing etc. This is the highest license level of ArcGIS for Desktop (ESRI, 2012). Mentioned software was chosen because of its most common use in the bodies of state administration and public authority in the Czech Republic, in comparison with other GIS solutions.

For the evaluation process it is necessary to collect sufficient data materials for researched territory, especially digital topological model of territory, and also other topographic data on other objects of interest such as settlements, economic and cultural buildings, pipelines, but also data on water flows, or general character of the landscape.

For the case study presented in this article, digital topographic model of the Czech Republic territory derived from the image base map of the Czech Republic 1:10 000 ZABAGED created by the Czech Office for Surveying, Mapping and Cadastre was chosen (ZABAGED, 2012). As an additional data source ZABAGED extension containing water information DIBAVOD intended to create thematic cartographic outputs with water management topics and themes of water protection was used. Administrator and provider of data is T. G. Masaryk Water Research Institute (DIBAVOD, 2012) and data are provided free of charge. They are also used in some data belonging to Nature Conservation Agency of the Czech Republic concerning the classification of protected landscape areas.

\section{Results}

The essential prerequisite of social, technical and environmental safety for spatial development is to assess preventively all possible risks of planned spatial development and minimize them prior 
to the realization of spatial development. The safety assessment for spatial development is rather a complicated activity during which it is necessary to consider a large number of various input data and factors, which may significantly affect these data, in particular time and location.

In this part authors present a safety assessment tool for spatial development, which was developed to support a proactive approach to environmental safety. This tool is based on the principle of semi-quantitative assessment of potential negative spatial development aspects and areas of their possible impact. The aim is to assess realistically the potential hazards resulting from spatial development. The tool was developed in compliance with national legal regulations and thus the process of impact assessment will be acceptable from both technological and legislative viewpoints.

\section{Assessment process of algorithm}

The following part of the article outlines the structure of the assessment process of algorithm evaluating the impacts of spatial development on population, infrastructure and the environment. This algorithm defines basic relations among individual elements of the process, which are divided into two basic groups: (1) the group of hazards, which includes individual negative aspects of spatial development (ISO, 2004); (2) the group of assets, which includes population, infrastructure and the environment. The algorithm itself consists of individual steps, which result in determining the level of potential risk that the elements of the asset group will be damaged due to spatial development (see Fig. 1).

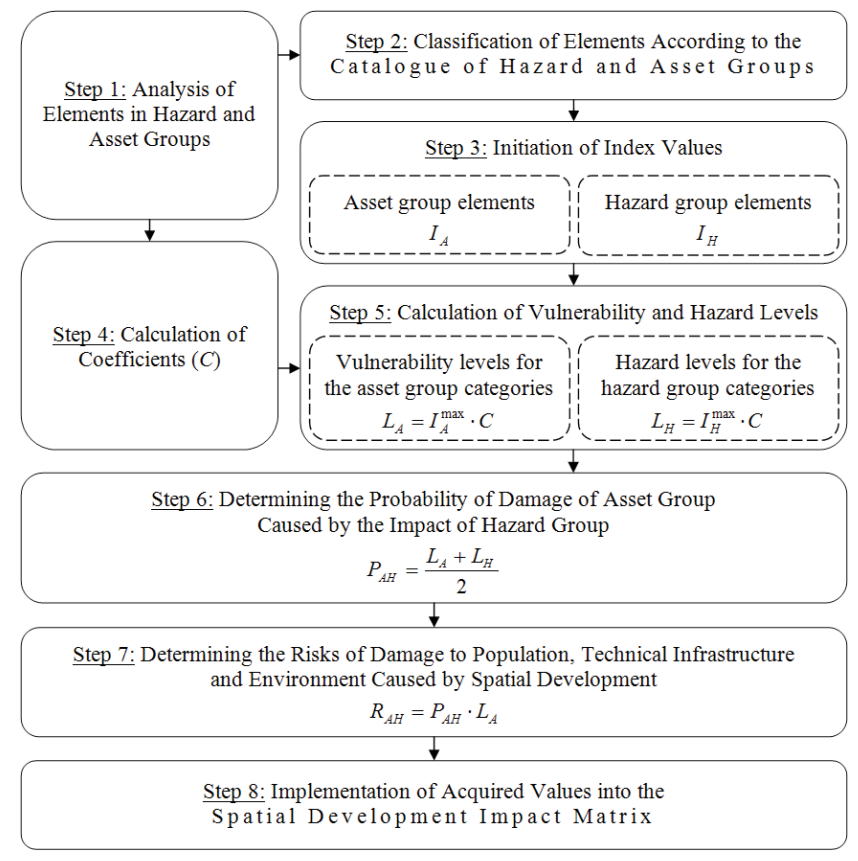

Fig. 1. Assessment process of algorithm. 


\section{Step 1: Analysis of elements in hazard and asset groups}

The analysis of elements in hazard and asset groups is the essential step in the assessment process of algorithm. The analysis consists in the setting of all social, technical and environmental aspects of planned spatial development with the potential negative impacts on population, technical infrastructure and the environment. This part of the analysis may be carried out according to the data from territorial plans or available indicators. The analysis of the elements of the asset group located in the planned area of spatial development consists in identifying all elements within the subgroups entitled as population, technical infrastructure and the environment, the value of which may be reduced or totally lost due to the negative impact of threats. This analysis may use information from maps and state administration authorities (e.g. district fire rescue corps, regional government and municipal authorities).

Step 2: Classification of elements according to the catalogue of hazard and asset groups In the next step, it is necessary to classify the elements according to the catalogue of hazard and asset groups, which consists of individual categories and their elements. There are the categories of hazard group (i.e. the individual negative aspects of spatial development) and the categories of the asset group (i.e. categories of the population, technical infrastructure and the environment).

Step 3: Initiation of index values of the elements in hazard and asset groups

Once the elements are classified into categories it is necessary to initiate the index values of the elements of hazard group $\left(I_{H}\right)$ and the elements of the asset group $\left(I_{A}\right)$. Thus, the elements are assigned corresponding index values.

\section{Step 4: Calculation of coefficients}

Another step of the algorithm is the calculation of coefficients $(C)$. The user adds selected criteria into preset formulae and then various coefficients are calculated for both hazard group and asset group. The final coefficients consider variables such as range, frequency and probability.

\section{Step 5: Calculation of hazard and vulnerability levels}

The calculation of hazard levels for individual categories of hazard group $\left(L_{H}\right)$ and vulnerability levels for individual categories of the asset group $\left(L_{A}\right)$ is made with the help of easy mathematical operations. The level of each category is calculated as the product of maximum index value of initiated elements belonging to the given category and coefficients - see formula (1).

$$
L=I^{\max } \cdot C
$$

Step 6: Determining the probability of damage of the asset group caused by the impact of hazard group

Determining the probability of damage $\left(P_{H A}\right)$ of the asset group caused by the impact of hazard group starts from the logical reasoning that this probability of damage is the highest if 


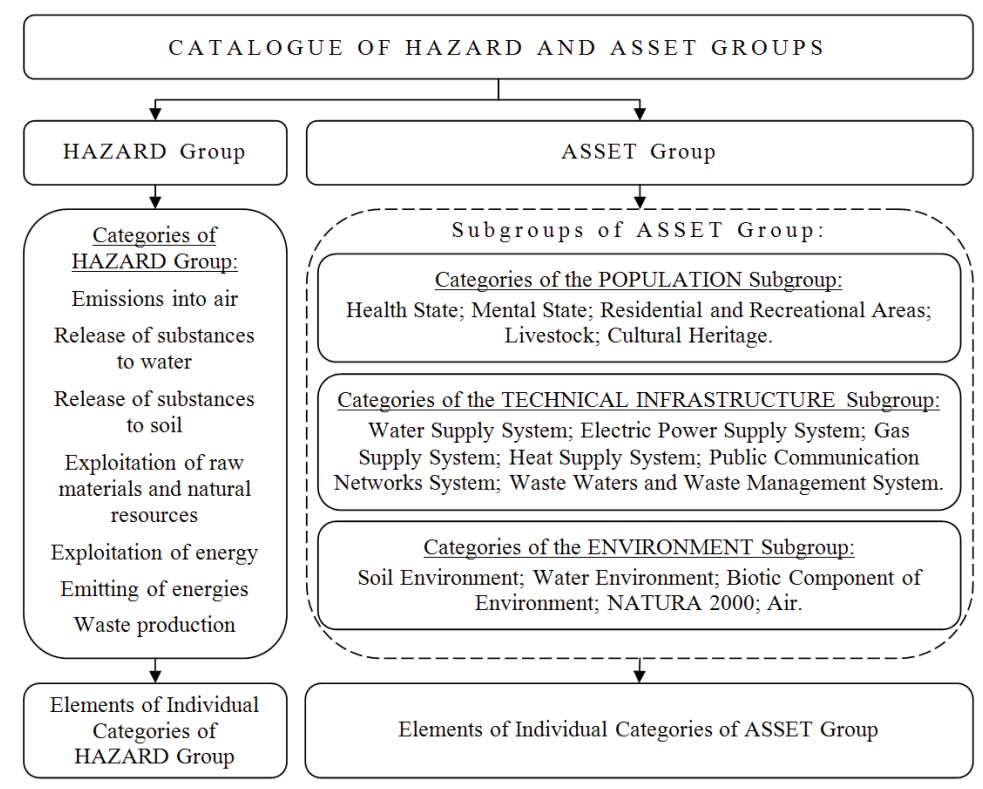

Fig. 2. Catalogue of hazard and asset groups.

the category with the highest level of hazard has an impact on the category with the highest level of vulnerability and vice versa. Mathematically the probability of damage is determined by the arithmetic average of hazard and vulnerability levels of the assessed categories (see section 'Relations defining assessment process of algorithm').

Step 7: Determining the risks of damage to population, technical infrastructure and environment caused by spatial development

Last step in the assessment process is determining the risks of damage to population, technical infrastructure and the environment caused by spatial development $\left(R_{H A}\right)$. The calculation of such risk is based on general platforms (ISO, 2009; Rehak, 2012). The level of risk is then determined as the product of vulnerability level of a category of the asset group and the probability related to the assessed categories of hazard and asset groups (see section 'Relations defining assessment process of algorithm').

Step 8: Implementation of acquired values into the spatial development impact matrix The outcome of the assessment process will be the matrix presenting the potential level of risk for population, technical infrastructure and the environment caused by intended spatial development (see section 'Spatial development impact matrix').

\section{Catalogue of hazard and asset groups and coefficients}

The catalogue of hazard and asset groups is a significant part of method for safety assessment of the spatial development. It consists of individual categories and elements. These categories 
$\mathrm{T}$ a b le 1. Asset group elements.

\begin{tabular}{|c|c|}
\hline Categories & Elements $\left(I_{A}\right)$ \\
\hline \multirow{8}{*}{ Soil environment } & Arable soil \\
\hline & Hop-field and vineyard \\
\hline & Garden \\
\hline & Orchard \\
\hline & Meadows and pastures \\
\hline & Non-agricultural land of agricultural land resources \\
\hline & Lands with stands of green vegetation \\
\hline & Developed areas and roads \\
\hline \multirow{8}{*}{ Water environment } & Sources of drinking water and their first level protection zones \\
\hline & Water sources' second level protection zones \\
\hline & Protection zones of natural water accumulation \\
\hline & Natural resources \\
\hline & Sources of ground and natural mineral waters \\
\hline & Water bodies used for fish and poultry farming \\
\hline & Water bodies used for recreation \\
\hline & Other water courses, bodies (both natural and man-made) \\
\hline \multirow{16}{*}{ Biotic component of environment } & First zone of a national park and protected landscape area \\
\hline & Second zone of a national park and protected landscape area \\
\hline & Third zone of a national park and protected landscape area \\
\hline & Fourth zone of a national park and protected landscape area \\
\hline & National nature reserve \\
\hline & National natural monuments \\
\hline & Nature reserve \\
\hline & Natural monuments \\
\hline & Significant landscape components \\
\hline & Temporarily protected areas \\
\hline & Nature parks \\
\hline & Territorial systems of ecological stability \\
\hline & Protection forests \\
\hline & Other forests \\
\hline & Tree monuments, their groups and avenues of trees \\
\hline & Other areas without special protection \\
\hline \multirow{2}{*}{ NATURA 2000} & Bird protection area \\
\hline & Area of European significance \\
\hline \multirow{3}{*}{ Air } & $\begin{array}{l}\text { High polluted air quality (average annual air pollution PM10 exceeds per- } \\
\text { mitted air quality standards } 40 \mu \mathrm{g} / \mathrm{m}^{3} \text { ) }\end{array}$ \\
\hline & $\begin{array}{l}\text { Considerably polluted air quality (average annual air pollution PM10 } \\
\text { achieves values between } 31 \text { and } 40 \mu \mathrm{g} / \mathrm{m}^{3} \text { ) }\end{array}$ \\
\hline & $\begin{array}{l}\text { Negligible polluted air quality (average annual air pollution PM10 does } \\
\text { not exceed value of } 30 \mu \mathrm{g} / \mathrm{m}^{3} \text { ) }\end{array}$ \\
\hline \multirow[b]{2}{*}{ Cultural heritage } & Area of planned spatial development with protection zones/heritage zones \\
\hline & $\begin{array}{l}\text { Area of planned spatial development without protection zones/heritage } \\
\text { zones }\end{array}$ \\
\hline
\end{tabular}


are classified into the categories of hazard group and the categories of the asset group. Individual categories then include elements, to which appropriate index values are assigned. The index values consider their hazardousness (in case of hazard group elements) and vulnerability (in case of the asset group elements). The structure of the catalogue of hazard and asset groups is shown in Fig. 2.

\section{Asset group elements}

On the basis of complex environmental analysis environmental elements were classified (Allaby, 2000) into the individual categories of the asset group (see Table 1). These elements are classified with respect to land use.

\section{Hazard group elements}

On the basis of complex analysis of the environmental aspects for spatial development, aspects were classified (Council Directive, 1985) into the individual categories of the group of threats (see Table 2).

T a b le 2. Hazard group elements.

\begin{tabular}{|c|c|}
\hline Categories & Elements (IH) \\
\hline \multirow{6}{*}{ Emissions into air } & $\begin{array}{l}\text { Mobile sources of air pollution - high traffic density (e.g., highways, main } \\
\text { roads, urban areas and other frequented stretches) }\end{array}$ \\
\hline & Mobile sources of air pollution - low traffic density \\
\hline & Stationary sources of air pollution - particularly large combustion sources \\
\hline & Stationary sources of air pollution - large combustion sources \\
\hline & Stationary sources of air pollution - medium combustion sources \\
\hline & Stationary sources of air pollution - small combustion sources \\
\hline \multirow{5}{*}{$\begin{array}{l}\text { Release of substances to } \\
\text { water }\end{array}$} & $\begin{array}{l}\text { The management of waste or mine water containing particularly hazardous } \\
\text { harmful substances }\end{array}$ \\
\hline & $\begin{array}{l}\text { The management of waste or mine water containing hazardous harmful sub- } \\
\text { stances }\end{array}$ \\
\hline & $\begin{array}{l}\text { The management of waste or mine water contaminated by the radioactive } \\
\text { substances }\end{array}$ \\
\hline & The management of waste or mine water containing no harmful substances \\
\hline & $\begin{array}{l}\text { The management of oil substances, particularly hazardous substances, radio- } \\
\text { active emitters and radioactive wastes }\end{array}$ \\
\hline \multirow{4}{*}{ Release of substances to soil } & The management of particularly hazardous harmful substances \\
\hline & The management of hazardous harmful substances \\
\hline & The management of radioactive substances \\
\hline & The management of fertilizers and chemical spraying \\
\hline \multirow{3}{*}{ Emitting of energies } & The management of waste water containing waste heat \\
\hline & Operation of facilities emitting radiation hazardous to health \\
\hline & Operation of source noise or vibration \\
\hline \multirow{4}{*}{ Waste production } & Hazardous waste production \\
\hline & Municipal waste production \\
\hline & Inert waste production \\
\hline & Production of biodegradable waste \\
\hline
\end{tabular}


The above list of categories and elements of the environmental aspects for spatial development (Table 2) should be considered only as a framework because in the context of spatial development a number of specific environmental aspects can occur. On this basis, it seems appropriate to create an international publicly accessible register of spatial development environmental aspects in which all environmental aspects related to spatial development were implemented by authorities (e.g. ministries involved). Data from the register would be used as a free accessible database to all the professional bodies involved in the issue of environmental impact assessment for spatial development.

Register of environmental aspects for spatial development should include basic data relating to environmental aspects of the spatial development elements. These data should be a functional component of spatial development, a specific element of spatial development, the category of environmental aspect, environmental aspect (activity or element), specific pollutants and the legislation relating to that aspect.

\section{Coefficients}

The consideration of variable parameters (e.g. scope, frequency and probability) elements presented above is used as coefficients. These coefficients have a regulatory function of possible variations in the hazard or vulnerability assessed elements (e.g. the increasing hazardousness of the element of spatial development in relation to the frequency of hazardous substances and waste management) and ensures more accurate outcomes in determining the levels of hazards and vulnerabilities in the individual categories of threat and asset groups. The coefficients are aimed to increase the levels of particular categories according to the current state of variables. The coefficients may be divided into two categories according to their relation to groups of hazards and assets as follows:

- Coefficients related to the group of threats

- Water or soil pollution burden $\left(C_{W S}\right)$

- $\quad$ Frequency of energy emitting $\left(C_{E}\right)$

- $\quad$ Frequency of hazardous substances management and waste management $\left(C_{P}\right)$

- Coefficients related to the group of assets

- $\quad$ Level of damage to the area of spatial development $\left(C_{D}\right)$

\section{Relations defining assessment process of algorithm}

On the basis of determination of vulnerability and hazard of group's assets elements and threats and the definition and evaluation coefficients can proceed to relations defining an algorithm assessment process. These relations are a key element in the function of the algorithm and consist of the relations for setting the levels of vulnerability and hazardousness and relations for determining the level of potential risk.

\section{Determination of the level of vulnerability and hazardousness}

In the following part of contribution are defined relations that are the basis for calculating the level of vulnerability $\left(L_{A}\right)$ for each category of asset groups and levels of dangerousness 
$\left(L_{H}\right)$ for each category of threat groups. Defining formulas is realized by using simple mathematical operations. The level of vulnerability and dangerousness of each category will always be the result of the maximum calculated index values initiated by elements belonging to the category and the relevant coefficients - see formula (1). For each category the following formulas were defined:

\section{Categories of the asset group}

- Vulnerability level of category 'soil medium'

$$
L_{A(S)}=I_{S}^{\max } \cdot C_{D}
$$

- Vulnerability level of category 'water medium'

$$
L_{A(W)}=I_{W}^{\max } \cdot C_{D}
$$

- Vulnerability level of category 'biota'

$$
L_{A(B)}=I_{B}^{\max } \cdot C_{D}
$$

- Vulnerability level of category 'NATURA 2000'

$$
L_{A(N)}=I_{N}^{\max } \cdot C_{D}
$$

- Vulnerability level of category 'air medium'

$$
L_{A(A)}=I_{A}^{\max } \cdot C_{D}
$$

- Vulnerability level of category 'cultural heritage'

$$
L_{A(K)}=I_{K}^{\max }
$$

\section{Categories of hazard group}

- Hazardousness level of category 'emissions to air medium'

$$
L_{H(A)}=I_{A}^{\max }
$$

- Hazardousness level of category 'release of substance to water medium'

$$
L_{H(W M)}=I_{W M}^{\max } \cdot C_{W S} \cdot C_{P}
$$

- Hazardousness level of category 'release of substance to soil medium'

$$
L_{H(S M)}=I_{\overline{S M}}^{\max } \cdot C_{W S} \cdot C_{P}
$$

- Hazardousness level of category 'emitting energy'

$$
L_{H(E)}=I_{E}^{\max } \cdot C_{E}
$$

- Hazardousness level of category 'waste production'

$$
L_{H(P)}=I_{P}^{\max } \cdot C_{P}
$$




\section{Determination of the level of potential risk}

On the basis of defining relations for each category of asset groups and threats can proceed with a single defining relation for the calculation of the level of potential risk. Level of potential risk will be calculated within the assessment for interaction of each category of asset groups with each category of threats. The formula for calculating is based on formula (2), which reflects a general platform of risk calculation (Rehak, 2012).

$$
R=P \cdot R I
$$

where $R$ is the risk level, $P$ is the probability, $R I$ is the range of impact.

The first essential factor in the calculation of the potential risk level is the probability of environmental damage due to spatial development. For determining, the key was made, based on judgement that the probability of adverse events (i.e. damage to the environment) is the highest when interacting most vulnerable and the most dangerous categories, i.e. if the value $L_{A}=3$ and $L_{H}=3$, then the highest probability and vice versa if the value of $L_{A}=1$ and $L_{H}=1$, then the probability is the lowest. This means that the basis for determining the probability is the knowledge of the interaction value $\left(V_{I}\right)$ of the studied categories of asset groups and threats. This value can be obtained through the average level of vulnerability of the asset group category and the level of danger of the threat group category - see formula (3).

$$
V_{I}=\frac{L_{A}+L_{H}}{2}
$$

The second step is to perform the recalculation of the resulting values to the probability of interaction and ensure the correct mathematical notation, i.e. as a percentage. Through the above-mentioned key, interaction values can be divided into five resulting variants, into five equal probability intervals to their corresponding median values of probability $\left(P_{A H}\right)$. This recalculation is done in Table 3.

T a b le 3. Recalculation of interaction value to probability value.

\begin{tabular}{|c|c|c|}
\hline Interaction value & Probability at intervals & Median values of probability $\mathbf{P}_{\mathrm{AH}}$ [\%] \\
\hline 1.0 & $<0 ; 20>$ & 10 \\
\hline 1.5 & $(20 ; 40>$ & 30 \\
\hline 2.0 & $(40 ; 60>$ & 50 \\
\hline 2.5 & $(60 ; 80>$ & 70 \\
\hline 3.0 & $(80 ; 100>$ & 90 \\
\hline
\end{tabular}

This method of recalculation, while ensuring that the probability never reaches the limit values, i.e. 0 and $100 \%$, because of their practical feasibility is quite impossible. Based on all the above procedures and conditions (i.e. set keys) formula (4) can be determined, whereby it is possible to convert all values of interaction $\left(V_{I}\right)$ into the values of probability $\left(P_{A H}\right)$. 


$$
P_{A H}=V_{I} \cdot 0,4-0,3
$$

whereas $P_{A H} \in\langle 0,1 ; 0,9\rangle$.

The second factor in the calculation of the level of potential risk is the range of the impact of spatial development on the environment or the potential extent of environmental damage due to spatial development. In determining the range of impact can be assumed, that in case of negative interaction of the asset group category with threat group category, will be harmed in the category of the asset group (such as damage due to substance release into the soil). At the same time it is evident that the higher vulnerability of the asset group category will then be in direct proportion higher by consequence of damage and vice versa. This formula can be expressed as (5).

$$
R I=L_{A}
$$

Based on the above, instead of range of impact, the level of vulnerability of the asset group category can be substituted into the relation for calculating the potential risk level. The resulting formula (6) for the calculation of the potential risk level then has the following notation.

$$
R_{A H}=P_{A H} \cdot L_{A}=\left(\frac{L_{A}+L_{H}}{2} \cdot 0,4-0,3\right) \cdot L_{A}
$$

where $R_{A H}$ is the risk level of damage of the asset group category by influence of hazard group (e.g. environmental damage influence of environmental aspect for spatial development), $L_{A}$ is the level of vulnerability of the asset group category (e.g. environmental compartment), $L_{H}$ is the level of hazardousness of threats group categories (e.g. environmental aspect for spatial development).

As already mentioned, the level of potential risk will always be calculated separately for interaction of each asset group category with each threat group category. On this basis, into the formula (6) were substituted variables, which were already defined 21 formulas. With this clarity, a formula for calculating the potential risk level of soil medium damage due to release of substances into the soil is presented in formula (7).

$$
R_{S_{-} S M}=\left(\frac{L_{A(S)}+L_{H(S M)}}{2} \cdot 0,4-0,3\right) \cdot L_{A(S)}
$$

where $R_{S S M}$ is the potential risk level of soil medium damage influence of substance release to soil, $L_{A(S)}$ is the level of vulnerability of soil medium category, $L_{H(S M)}$ is the level of hazardousness of substance release to soil category. 


\section{Spatial development impact matrix}

The final risks of damage of population, technical infrastructure and the environment caused by the intended spatial development are in the final phase of assessment demonstrated in the spatial development impact matrix (see Fig. 3).

\begin{tabular}{|c|c|c|c|c|c|c|c|c|}
\hline \multirow{2}{*}{\multicolumn{2}{|c|}{$\begin{array}{l}\text { SPATIAL DEVELOPMENT } \\
\text { IMPACT MATRIX }\end{array}$}} & \multicolumn{7}{|c|}{ Potential Negative Aspects of Spatial Development } \\
\hline & & $\mathrm{A}_{\mathrm{A}}$ & $\mathrm{A}_{W}$ & $A_{S}$ & $A_{R}$ & $A_{X}$ & $A_{E}$ & $A_{P}$ \\
\hline \multirow{5}{*}{ 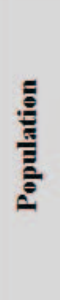 } & Health State & & & & & & & \\
\hline & Mental State & & & & & & & \\
\hline & $\begin{array}{l}\text { Residential and Recreational } \\
\text { Areas }\end{array}$ & & & & & & & \\
\hline & Livestock & & & & & & & \\
\hline & Cultural Heritage & & & & & & & \\
\hline \multirow{6}{*}{ 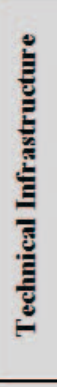 } & Water Supply System & & & & & & & \\
\hline & $\begin{array}{l}\text { Electric Power Supply } \\
\text { System }\end{array}$ & & & & & & & \\
\hline & Gas Supply System & & & & & & & \\
\hline & Heat Supply System & & & & & & & \\
\hline & $\begin{array}{l}\text { Public Communication } \\
\text { Networks System }\end{array}$ & & & & & & & \\
\hline & $\begin{array}{l}\text { Waste Waters and Waste } \\
\text { Management System } \\
\end{array}$ & & & & & & & \\
\hline \multirow{5}{*}{ 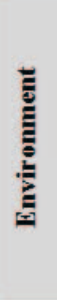 } & Soil Environment & & & & & & & \\
\hline & Water Environment & & & & & & & \\
\hline & $\begin{array}{l}\text { Biotic Component of } \\
\text { Environment }\end{array}$ & & & & & & & \\
\hline & NATURA 2000 & & & & & & & \\
\hline & Air & & & & & & & \\
\hline
\end{tabular}

Fig. 3. Spatial development impact matrix.

$A_{A}$ - Emissions into air

$A_{W}$ - Release of substances to water

$A_{s}$ - Release of substances to soil

$A_{R}$ - Exploitation of raw materials and natural resources

$A_{X}$ - Exploitation of energy

$A_{E}$ - Emitting of energies

$A_{p}$ - Waste production

Note: The cross-hatched field signals that the given aspect and category are not related and therefore the level of risk is not determined for this relation. 
The outcome of the assessment process will be the matrix presenting the potential level of risk for population, infrastructure and the environment caused by intended spatial development. Such a risk will be classified into three categories, which for the purpose of the method is a sufficient distinguishing capability.

The description of individual risk categories and the determination of acceptability of potential risk as well as measures to be taken (i.e. the recommendations which should be followed by the assessor) are as follows:

- The A category of risk level: Spatial development indicates a low potential risk of damage to the environment in the assessed area (the risk is acceptable). Even potentially highly hazardous elements may be located in the given area when standard safety measures are followed. This category of risk is a necessary prerequisite for building new industrial facilities.

- The B category of risk level: Spatial development indicates an increased potential risk of damage to the environment in the assessed area (it is necessary to reduce such a risk). It is not suitable to carry out the planned spatial development in the given area. It is recommended to look for another area or modify the spatial development so that it does not cause damage to the environment. At the same time, it is recommended to reassess the planned spatial development and possibly replan it.

- The C category of risk level: Spatial development indicates a high potential risk of damage to the environment in the assessed area (the risk is unacceptable). This category indicates that it is most probable that the planned spatial development will cause an extensive and serious damage to the environment in the given area. Therefore, it is recommended to not only look for another less vulnerable area, but also thoroughly check the range and level of hazard of the planned spatial development.

\section{Software support for spatial development impact assessment}

A significant application support for assessment of safety of spatial development is a developed software tool for spatial development impact assessment. The first part of the software tool is public and contains basic information about the application and the entry of potential users in the authenticated section for the purpose of the evaluation process. A software tool is located on the Web address at <http://fbiweb.vsb.cz/sdia>.

The second part of the software tool includes the process of evaluation, which is located in the authenticated section of the application (see Fig. 4). This section is secured to prevent access to undesirable persons. Specified users receive relevant login and password upon request from the administrator. The section consists of a user and an administrator setting. The user interface includes evaluation forms, the results in the form of matrix of spatial development impacts and final protocols from the evaluations.

\section{Case study}

This part of article presents a case study aimed at evaluating the environmental safety of spatial development for the hazardous waste incineration plant planned to situate into three 


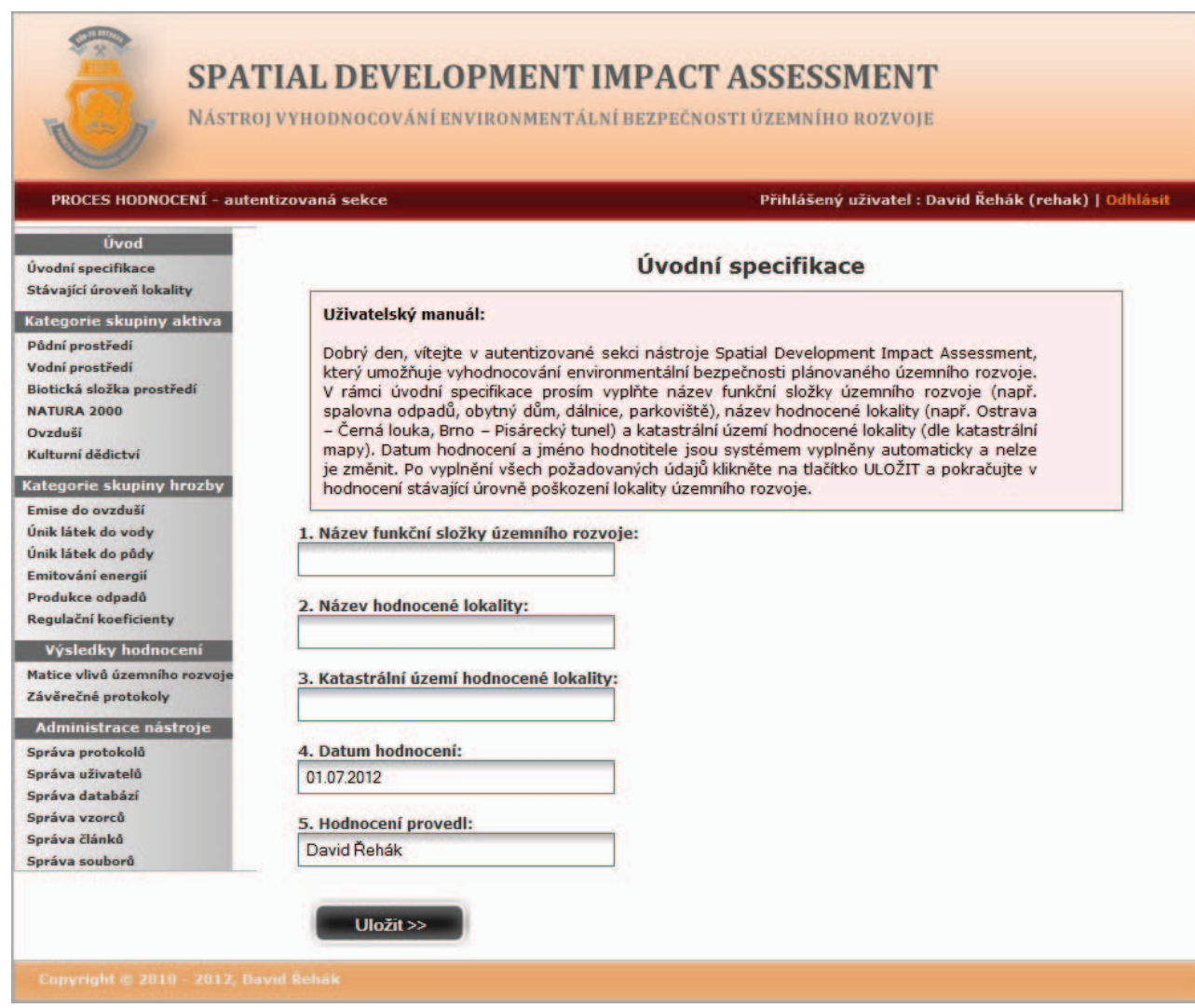

Fig. 4. Authenticated section of software tool for spatial development impact assessment.

different interest areas located in the Moravian-Silesian Region (Řehák et al., 2011c). Finally, the results are presented, and suitable measures are proposed to reduce the potential risks of the intended spatial development.

Description and results from analysis aimed at the selected functional component of spatial development

Functional component of spatial development, which was selected for the case study, is the high capacity incineration plant of hazardous waste. Detailed specifications are as follows:

- Planned activities: loading, storage and incineration of hazardous waste

- Incineration plant capacity: 15 tons/day (1 rotary furnace)

- $\quad$ Accepted waste: solid, soggy, liquid

- Kind of accepted waste: industrial hazardous waste, waste from health and veterinary care

- Method of waste dosing: grab, ladles, nozzle 
Based on the analysis, specific negative environmental aspects which were subsequently entered into the catalogue of hazard and asset groups were evaluated for the above functional components of spatial development (see Table 4).

$\mathrm{T} \mathrm{a} \mathrm{b} \mathrm{l} \mathrm{e} \mathrm{4.} \mathrm{The} \mathrm{results} \mathrm{of} \mathrm{analysis} \mathrm{of} \mathrm{the} \mathrm{functional} \mathrm{components} \mathrm{of} \mathrm{spatial} \mathrm{development.}$

\begin{tabular}{|c|c|c|}
\hline Categories & Elements $\left(I_{H}\right)$ & $\begin{array}{l}\text { Initiation } \\
\text { of elements }\end{array}$ \\
\hline \multirow[t]{6}{*}{ Emissions into air } & $\begin{array}{l}\text { Mobile sources of air pollution - high traffic density (e.g. } \\
\text { highways, main roads, urban areas and other frequented } \\
\text { stretches) }\end{array}$ & $\square$ \\
\hline & Mobile sources of air pollution - low traffic density & $\square$ \\
\hline & $\begin{array}{l}\text { Stationary sources of air pollution - particularly large } \\
\text { combustion sources }\end{array}$ & $\nabla$ \\
\hline & $\begin{array}{l}\text { Stationary sources of air pollution - large combustion } \\
\text { sources }\end{array}$ & $\square$ \\
\hline & $\begin{array}{l}\text { Stationary sources of air pollution - medium combustion } \\
\text { sources }\end{array}$ & $\square$ \\
\hline & $\begin{array}{l}\text { Stationary sources of air pollution - small combustion } \\
\text { sources }\end{array}$ & $\square$ \\
\hline \multirow[t]{5}{*}{ Emissions into air to water } & $\begin{array}{l}\text { The management of waste or mine water containing parti- } \\
\text { cularly hazardous harmful substances }\end{array}$ & $\square$ \\
\hline & $\begin{array}{l}\text { The management of waste or mine water containing ha- } \\
\text { zardous harmful substances }\end{array}$ & $\square$ \\
\hline & $\begin{array}{l}\text { The management of waste or mine water contaminating } \\
\text { radioactive substances }\end{array}$ & $\square$ \\
\hline & $\begin{array}{l}\text { The management of waste or mine water containing no } \\
\text { harmful substances }\end{array}$ & $\square$ \\
\hline & $\begin{array}{l}\text { The management of oil substances, particularly hazardous } \\
\text { substances, radioactive emitters and radioactive wastes }\end{array}$ & $\nabla$ \\
\hline \multirow[t]{4}{*}{ Release of substances to soil } & $\begin{array}{l}\text { The management of particularly hazardous harmful sub- } \\
\text { stances }\end{array}$ & $\nabla$ \\
\hline & The management of hazardous harmful substances & $\nabla$ \\
\hline & The management of radioactive substances & $\square$ \\
\hline & The management of fertilizers and chemical spraying & $\square$ \\
\hline \multirow[t]{3}{*}{ Emitting of energies } & The management of waste water containing waste heat & $\square$ \\
\hline & $\begin{array}{l}\text { Operation of facilities emitting radiation hazardous to } \\
\text { health }\end{array}$ & $\square$ \\
\hline & Operation of source noise or vibration & $\square$ \\
\hline \multirow[t]{4}{*}{ Waste production } & Hazardous waste production & $\square$ \\
\hline & Municipal waste production & $\nabla$ \\
\hline & Inert waste production & $\nabla$ \\
\hline & Production of biodegradable waste & $\square$ \\
\hline
\end{tabular}


For the purpose of verification of tool for Spatial Development Impact Assessment and possible links to GIS, area of interest situated in the Moravian-Silesian Region, in the south part of the regional city of Ostrava, close to the industrial zone Hrabová was selected (see Fig. 5). This area is also located close to the highway, so it is relatively easily available. For a more accurate idea of the location of the object, two buffer zones at a distance of $500 \mathrm{~m}$ and $1 \mathrm{~km}$ around the facility were created. The nearest residential buildings are to the edge of $500 \mathrm{~m}$ of buffer zone. Incinerator occupies an area measuring about 150×220 m.

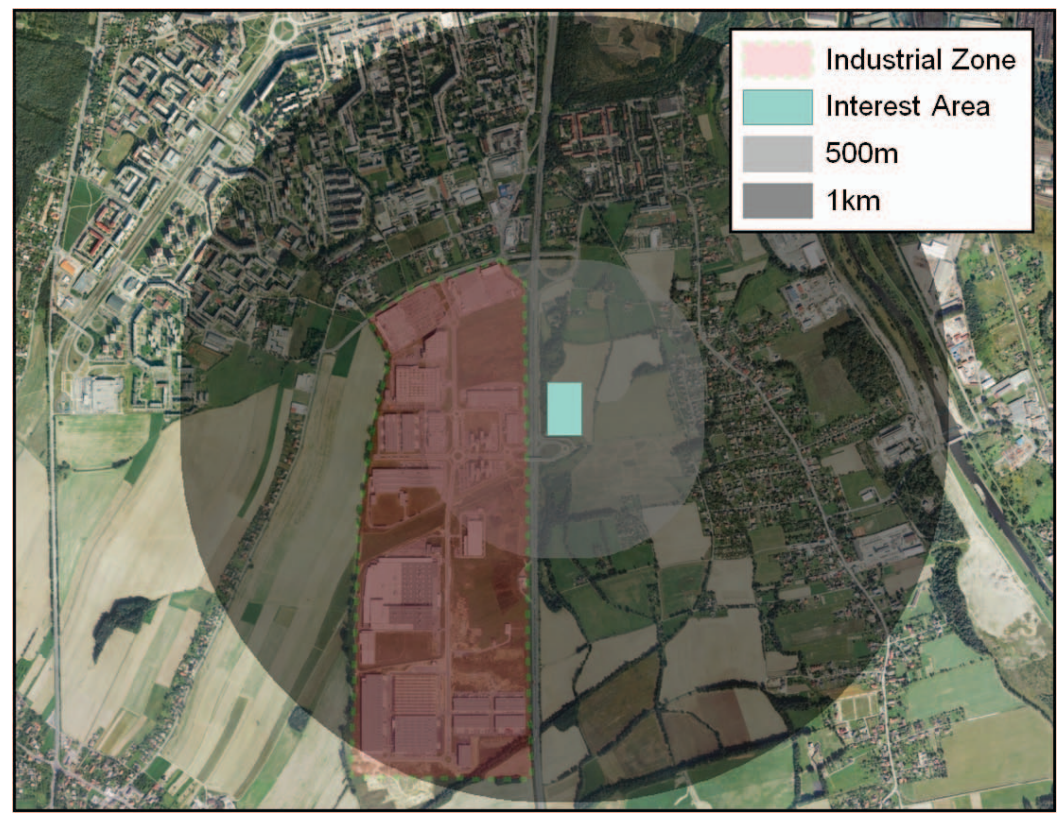

Fig. 5. The area of interest in the map documents.

On the basis of this analysis, the area of interest was identified by the occurrence of individual elements of the environment that may be in the realization of the intended spatial development damaged. This information was then entered into the catalogue of hazard and asset groups (see Table 5).

\section{The results of spatial development impact assessment}

Only after entering information into the catalogue of hazard and asset groups is it possible to assign the corresponding index values $(I)$ to initiated elements (i.e. the user-checked elements). These values were in the creation of spatial development impact assessment tool set by selected expert reviewers from the Czech Republic. Index values for the category of the asset group, however, are known to the user after marking the area of interest into a GIS, as this GIS is linked to the database of catalogue of hazard and asset groups. 
$\mathrm{T} \mathrm{a} \mathrm{b} \mathrm{l} \mathrm{e} \mathrm{5.} \mathrm{The} \mathrm{results} \mathrm{from} \mathrm{the} \mathrm{analysis} \mathrm{of} \mathrm{the} \mathrm{area} \mathrm{of} \mathrm{interest.}$

\begin{tabular}{|c|c|c|}
\hline Categories & Elements $\left(I_{A}\right)$ & \begin{tabular}{|l|l|}
$\begin{array}{l}\text { Initiation } \\
\text { of elements }\end{array}$ \\
\end{tabular} \\
\hline \multirow[t]{8}{*}{ Soil environment } & Arable soil & $\square$ \\
\hline & Hop-field and vineyard & $\square$ \\
\hline & Garden & $\square$ \\
\hline & Orchard & $\square$ \\
\hline & Meadows and pastures & $\nabla$ \\
\hline & Non-agricultural land of agricultural land resources & $\square$ \\
\hline & Lands with stands of green vegetation & $\square$ \\
\hline & Developed areas and roads & $\square$ \\
\hline \multirow[t]{8}{*}{ Water environment } & Sources of drinking water and their first level protection zones & $\square$ \\
\hline & Water sources second level protection zones & $\square$ \\
\hline & Protection zones of natural water accumulation & $\square$ \\
\hline & Natural resources & $\square$ \\
\hline & Sources of ground and natural mineral waters & $\square$ \\
\hline & Water bodies used for fish and poultry farming & $\square$ \\
\hline & Water bodies used for recreation & $\square$ \\
\hline & Other water courses, bodies (both natural and man-made) & $\square$ \\
\hline \multirow{16}{*}{$\begin{array}{l}\text { Biotic component } \\
\text { of environment }\end{array}$} & First zone of a national park and protected landscape area & $\square$ \\
\hline & Second zone of a national park and protected landscape area & $\square$ \\
\hline & Third zone of a national park and protected landscape area & $\square$ \\
\hline & Fourth zone of a national park and protected landscape area & $\square$ \\
\hline & National nature reserve & $\square$ \\
\hline & National natural monuments & $\square$ \\
\hline & Nature reserve & $\square$ \\
\hline & Natural monuments & $\square$ \\
\hline & Significant landscape components & $\square$ \\
\hline & Temporarily protected areas & $\square$ \\
\hline & Nature parks & $\square$ \\
\hline & Territorial systems of ecological stability & $\square$ \\
\hline & Protection forests & $\square$ \\
\hline & Other forests & $\square$ \\
\hline & Tree monuments, their groups and avenues of trees & $\square$ \\
\hline & Other areas without special protection & $\nabla$ \\
\hline \multirow[t]{2}{*}{ NATURA 2000} & Bird protection area & $\square$ \\
\hline & Area of European significance & $\square$ \\
\hline \multirow[t]{3}{*}{ Air } & $\begin{array}{l}\text { High polluted air quality (average annual air pollution PM10 exceeds } \\
\text { permitted air quality standards } 40 \mu \mathrm{g} / \mathrm{m} 3 \text { ) }\end{array}$ & $\square$ \\
\hline & $\begin{array}{l}\text { Considerably polluted air quality (average annual air pollution PM10 } \\
\text { achieves values between } 31 \text { and } 40 \mu \mathrm{g} / \mathrm{m} 3 \text { ) }\end{array}$ & $\nabla$ \\
\hline & $\begin{array}{l}\text { Negligible polluted air quality (average annual air pollution PM10 } \\
\text { does not exceed value of } 30 \mu \mathrm{g} / \mathrm{m} 3 \text { ) }\end{array}$ & $\square$ \\
\hline \multirow[t]{2}{*}{ Cultural heritage } & $\begin{array}{l}\text { Area of planned spatial development with protection } \\
\text { zones/heritage zones }\end{array}$ & $\square$ \\
\hline & $\begin{array}{l}\text { Area of planned spatial development without protection } \\
\text { zones/heritage zones }\end{array}$ & $\square$ \\
\hline
\end{tabular}


Consequently, it was possible to proceed to the calculation of the coefficients $(C)$, which consisted in putting the selected parameters to preconfigured formulas. The resulting coefficients reflect variable parameters, which are the extent, frequency or probability.

The obtained index values were then put into the formulas to calculate the vulnerability levels for the categories of the asset group $\left(L_{A}\right)$ and the hazard levels for the categories of threat group $\left(L_{H}\right)$. The level of each category was calculated by the multiple of the maximum index value initiated elements that belong to a given category and the relevant coefficients (see formula (1)).

In the next step, the probability $\left(P_{A H}\right)$ of damage of the asset group categories by the effect of group threat categories was determined. Mathematically, the probability of damage was determined by goniometric average level of hazard and the level of vulnerability assessing categories (see formula (3)).

The final step of the assessment process was to determine the level of risk of potential damage to the environment due to the intended spatial development $\left(R_{A H}\right)$. The risk level was then determined by the multiple of the level of vulnerability of the group asset category and the probability relevant to the assessed categories of threat and asset groups (see formula (5)). Results are clearly presented in the matrix of spatial development impact (see Fig. 6).

\begin{tabular}{|c|c|c|c|c|c|c|}
\hline \multirow{2}{*}{\multicolumn{2}{|c|}{$\begin{array}{l}\text { SPATIAL DEVELOPMENT } \\
\text { IMPACT MATRIX }\end{array}$}} & \multicolumn{5}{|c|}{ Categories of the HAZARD Group } \\
\hline & & \multirow[t]{2}{*}{$\mathbf{A}_{\mathbf{A}}$} & \multirow{2}{*}{$\begin{array}{c}\mathrm{A}_{\mathbf{W}} \\
\mathrm{B}_{2} \\
(1.47)\end{array}$} & \multirow{2}{*}{$\begin{array}{c}\mathrm{A}_{\mathbf{s}} \\
\mathrm{B}_{2} \\
(1.47)\end{array}$} & \multirow[t]{2}{*}{$A_{E}$} & \multirow{2}{*}{$\begin{array}{c}\mathrm{A}_{\mathbf{P}} \\
\mathrm{B}_{1} \\
(1.09)\end{array}$} \\
\hline$\widehat{\bar{z}}$ & Soil environment & & & & & \\
\hline 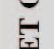 & Water environment & & & & & \\
\hline $\begin{array}{l}\overline{5} \\
\frac{3}{4} \\
0\end{array}$ & Biotic component of environment & $\begin{array}{c}\mathrm{B}_{1} \\
(0.55)\end{array}$ & $\begin{array}{c}\mathrm{B}_{1} \\
(0.62)\end{array}$ & $\begin{array}{c}\mathrm{B}_{1} \\
(0.62)\end{array}$ & & $\begin{array}{c}\text { A } \\
(0.41)\end{array}$ \\
\hline$\overline{0}$ & NATURA 2000 & & & & & \\
\hline 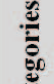 & Air & $\begin{array}{c}\mathrm{C} \\
(1.92)\end{array}$ & & & & \\
\hline$\tilde{\Xi}$ & Cultural heritage & & & & & \\
\hline
\end{tabular}

Fig. 6. Spatial development impact matrix (filled).

$A_{A}-$ Emissions into air

$A_{W}$ - Release of substances to water

$A_{S}$ - Release of substances to soil

$A_{E}$ - Emitting of energies

$A_{P}$ - Waste production

Note: The cross-hatched field signals that the given aspect and category are not related and therefore the level of risk is not determined for this relation.

The resulting levels of potential risk of damage of interest area due to spatial development are divided into four categories:

- Category A (0.1 to 0.45$)$ - acceptable risk

- Category B1 (0.46 to 1.20) - risk should be reduced 
- Category B2 (1.21 to 1.75$)$ - it is necessary to reduce the risk

- Category C (1.76 to $\infty$ ) - unacceptable risk

Visualization of results of the assessment of environmental safety in GIS is demonstrated on the environmental aspect of spatial development 'Waste Production' (see Fig. 7).

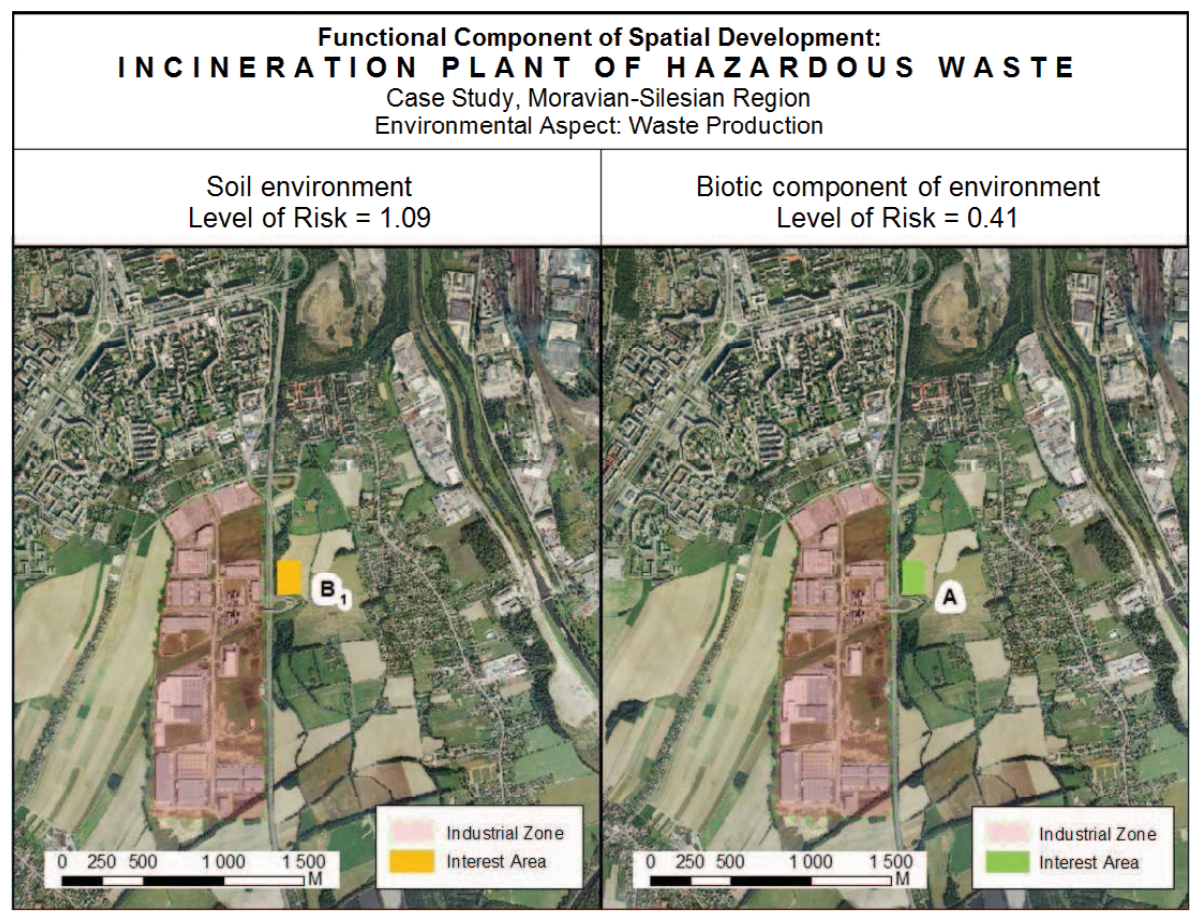

Fig. 7. Visualization of results in GIS.

The aim of the presented case study was to evaluate environmental safety of spatial development for the planned location of the hazardous waste incinerator in the selected area of interest which was located in the Moravian-Silesian Region in the Czech Republic. Based on the obtained results, the potential risk of damage to the environment due to spatial development can be divided into four categories.

As an acceptable risk (Categories A and B1) can be considered the potential negative impact of the intended incinerator on biotic component of environment, this risk can be further controlled, but it is not a condition of the realization of planned spatial development.

In contrast, the risk that it will be necessary to reduce (Category B2) has been found in the incinerator effect on soil environment. Totally unacceptable risk (Category C) was found in areas of incinerators impact on air. Based on the above, it is recommended either planned spatial development in the area to realize, but in this case, to ensure maximum possible air protection (e.g. using the latest modern technology end-of-pipe) or planned spatial development in the area do not realize and rather to make look for the better interest territory. 


\section{Conclusion}

The basic premise of social, technical and environmental safety of spatial development is a preventive assessment of all possible risks of the planned spatial development and then minimization prior to the realization of spatial development (Kozlowski, 1990). Just like in the case with a number of technical fields here can be used to improve the process, also various methods and tools for assessing impacts. In the analysis of technological risks, these tools currently present the best way for the prevention of activities with a negative impact on the population or on the environment (Bartlova, Balog, 2007; Senovsky et al. 2009). For this reason, it is an unquestionable fact a need to develop and apply a similar impact assessment tool for spatial development.

Based on the above mentioned and also existing knowledge in the field of methods and tools for impact assessment, it is proposed to ensure the safety of spatial development by using a simple algorithmic procedure that appears to be very useful for several reasons. Until now, there is no clear and universal tool to evaluate the impacts of spatial development on the population, technical infrastructure and the environment in relation to the intended land use plan. The universality of the algorithm is highlighted by the fact that it can be easily optimized and used in different countries, even those in which there are different legal rules and the value of territory planned for the development is quite variable. A relevant fact is that the presented tool for social, technical and environmental safety of spatial development is not prescriptive mechanism, but can be used as an informative tool recommending to evaluators if the planned spatial development in the area is suitable to realize or not.

Easy applicability of this algorithm in practice supports the presented software tool, which is available online through the Web interface. This tool can be updated or modified at any time, depending on the required outputs (Rehak, 2011). Modified version of the method presented in this article is currently used successfully, for example, by Army of the Czech Republic for the assessment of the impact of military training activities on people and the environment located close to military training areas (Rehak et al. 2010). Possibilities of modification and use of methods for the civilian sector are currently being discussed with the Fire Rescue Service of the Czech Republic.

\section{Acknowledgements}

The article is connected to a research, development and innovation project called 'Security of the population - crisis management', identification code VF20112015018. Project funding has been provided by the Ministry of Interior of the Czech Republic as part of its program 'Security Research for the Needs of the State 2010-2015'.

\section{References}

Act (2001). No 100/2001 Col. on environmental impact assessment. Collection of Acts of the Czech Republic (in Czech). Act (2006). No 183/2006 Col. on the spatial planning and building code. Collection of Acts of the Czech Republic (in Czech).

AIChE (2010). Dow's fire \& explosion index hazard classification guide. New York: American Institute of Chemical Engineers.

Allaby, M. (2000). Basics of environmental science. New York: Routledge.

Bartlova, I. \& Balog K. (2007). Hazard analysis and prevention of industrial accidents I (in Czech). Ostrava: SPBI.

Belčáková, I. (2012). Landscape planning framework in the environmental assessment - Linkages and mutual benefits. Ekológia (Bratislava), 31(1), 1-11. DOI: 10.4149/ekol_2012_01_1. 
Council Directive (1985). 85/337/EEC of $27^{\text {th }}$ June 1985 on the assessment of the effects of certain public and private projects on the environment.

Council Directive (1997). 97/11/EC of $3^{\text {rd }}$ March 1997 amending Directive 85/337/EEC on the assessment of the effects of certain public and private projects on the environment.

Danihelka, P., Sikorova, K. \& Tomasova B. (2006). Analysis of chemical accident impact on environment. In Proceedings of the European safety and reliability conference 2006. Safety and Reliability for Managing Risk, 3, 2233-2237.

DIBAVOD (2012). Digital base of water data. Accessed 23 October 2012, http://www.vuv.cz/oddeleni-gis/index.ph$\mathrm{p}$ ?id=27.

Directive (2001). 2001/42/EC of the European Parliament and of the Council of $27^{\text {th }}$ June 2001 on the assessment of the effects of certain plans and programmes on the environment.

ESRI (2012). ArcInfo. Accessed 9 November 2012, http://www.esri.com/software/arcgis/arcinfo/index.html.

Hrdina, P., Kotatko, A. \& Dobes P. (2010). Risk analysis of area unit with using of geographic information systems (in Czech). Spektrum, 10(1), 25-29.

ISO 14004 (2004). Environmental management systems - General guidelines on principles, systems and support techniques.

ISO 31000 (2009). Risk management - Principles and guidelines.

KATARISK (2003). Katastrophen und Notlagen in der Schweiz: eine Risikobeurteilung aus der Sicht des Bevölkerungsschutzes. Bern: Bundesamt für Zivilschutz.

Kozlowski, J.M. (1990). Sustainable development in professional planning: a potential contribution of the EIA and UET concepts. Landsc. Urban Plann., 19, 307-332.

Ministry of Environment (2004a). State environmental policy of the Czech Republic (in Czech). Praha.

Ministry of Environment (2004b). Strategy of sustainable development of the Czech Republic (in Czech). Praha.

Navratilova, A. et al. (2013). Principles and rules of spatial planning (in Czech). Brno: Institute for Spatial Development.

Řehák, D. \& Dvorak J. (2010). The assessment tool of social, technical and environmental security of spatial development. Safety Engineering Serie, 5(2), 89-99.

Řehák, D., Dvorak, J., Novotna, L. \& Komar A. (2010). Methodical instructions for providing the Environmental Safety of Military Training Activities Conducted Outside Military Training Areas (Certified methodology) (in Czech). Praha: Ministry of Defence.

Řehák, D. (2011). Population protection against the indirect negative impacts of spatial development in the context of sustainable development of territory (in Czech). Habilitation thesis, VSB-Technical University, Ostrava.

Řehák, D., Dvorak, J. \& Danihelka P. (2011a). Algorithm of the process of military training activities environmental impact assessment: Hazard and Impact Index. Ekológia (Bratislava), 30(1), 110-121. DOI: 10.4149/ekol_2011_01_110.

Řehák, D., Senovsky, M., Balog, K. \& Dvorak J. (2011b). Analytical Tool for Risk Assessment of Landscape and Urban Planning: Spatial Development Impact Assessment. Central European Journal of Engineering, 1(2), $202-209$. 10.2478/s13531-011-0018-5

Řehák, D., Hrdina, P., Senovsky, M. \& Dvorak J. (2011c). Case study on the spatial development impact assessment tool applied in the spatial development environmental security assessment. Communications - Scientific Letters of the University of Zilina, 13(2), 32-36.

Řehák, D. (2012). Introduction to risk management. In L. Lukas (Ed.), Bezpečnostní technologie, systémy a management II (in Czech). Zlín: VeRBuM.

Senovsky, M., Adamec, V., Krocova, S. \& Senovsky P. (2009). Assessment of Risks of Critical Infrastructure Elements (in Czech). Spektrum, 9(1), 5-7.

Sikorova, K. (2009). Environmental Impact Assessment in the context of management of major accident prevention (in Czech). Doctoral thesis, VSB-Technical University, Ostrava.

SIPROCI (2007). Risk Mapping a Proposal for a Common European Methodology. Project coordinator EuroCentro.

Vojkovska, K. \& Danihelka P. (2002). Methodology for the environmental impact analysis of accidents involving hazardous substances (Hazard \& Vulnerability Index) (in Czech). Ostrava: VSB-Technical University.

ZABAGED (2012). Fundamental base of geographic data. Accessed 23 October 2012, http://www.cuzk.cz/Dokument. aspx?PRARESKOD=998\&MENUID=10384\&AKCE=DOC:10-ENG1. 